\title{
Inhibition of the fungus Colletotrichum lindemuthianum in the presence of different potassium sorbate concentrations
}

Fernanda Engel ${ }^{1}$

Antônio Azeredo Coutinho Neto²

\section{Abstract}

One of the major problems of in vitro plant cultivation is caused by contaminations such as fungal, which represent great losses for plant cultivation laboratories. In view of the problem about contamination and gaps in efficient disinfection protocols, the present study aimed to evaluate the inhibition of the fungus Colletotrichum. lindemuthianum in the presence of the potassium sorbate food preservative at different concentrations $\left(0 \mathrm{~g} \mathrm{~L}^{-1} ; 0.076 \mathrm{~g} . \mathrm{L}^{-1} ; 0.15 \mathrm{~g} . \mathrm{L}^{-1} ; 0.30 \mathrm{~g} . \mathrm{L}^{-1} ; 0.45 \mathrm{~g} . \mathrm{L}^{-1}\right.$; $0.60 \mathrm{~g}$. $\mathrm{L}^{-1}$ and $0.75 \mathrm{~g}$. $\mathrm{L}^{-1}$ ). The analyses of the Percentage of Micelal Growth Inhibition (ICP) and the growth at 24 and 72 hours at different concentrations were quantified. It was observed that Potassium Sorbate was effective in the analysis of ICP at different concentrations in relation to control, with greater effectiveness for T4 to T7. The highest percentages of inhibition (T5 to T7) presenting an inhibition rate of mean mycelial growth of $17.5 \%$ in relation to the control for the $72 \mathrm{~h}$ period, indicating, therefore, that with further studies this preservative can be used to combat fungal microorganisms in vitro culture. Keywords: Inhibition. Microorganism. In vitro contamination. Fungal inhibition. Mycelial growth. Food preservative.

\section{Introduction}

The development and improvement of plant manipulation techniques in vitro contributes to the production of plant species on a large scale and at all times of the year (LEIFERT; CASSELLS, 2003). These techniques consist of the production of clones of a plant from an explant, and the complete regeneration of a fragment to a complete plant is based on the principle of cellular totipotence, and at the end, a plant will be obtained that will present the same genotypic constitution as the one that gave rise to it (TORRES et al., 2000).

Despite numerous advantages found in large-scale in vitro production, some problems have not yet been fully or safely solved, such as contamination, which cause large losses of plant material and which are possibly the mains problems encountered in tissue culture (GRATTAPAGLIA; MACHADO, 1998; LEIFERT MORRIS; WAITES, 1994; CASSELS, 2000b). Contaminations can occur by fungi, yeasts, bacteria, viruses, and also by the operator who manipulates plant material (GEORGE, 1993; CASSELS, 2000a). Thus, to inhibit or minimize the problem resulting from contamination, numerous disinfection procedures and protocols are used in in vitro micropropagation laboratories (YEPES; ALDWINCKLE, 1994; PIERIK, 1997; VIANA et al., 1997; PASQUAL, 2001; HIRATA; MANCINIFILHO, 2002; COLOMBO et al., 2004; EMMANUEL et al., 2004).

1 Universidade do Vale do Itajaí (UNIVALI). Estudante de Pós-Graduação (Doutorado em Ciência e Tecnologia Ambiental). fernanda_engel@hotmail.com.

2 Universidade de São Paulo (USP). Estudante de Pós-Graduação (Mestrado em Ciências Biológicas). antonioacneto@biologo.bio.br. 
A possibility in view of the problem of contamination is the use of food preservatives such as Potassium Sorbate $\left(\mathrm{C}_{6} \mathrm{H}_{7} \mathrm{O}_{2} \mathrm{~K}\right)$, added to the culture medium, considering that it is already widely used in various foods, cosmetics, and pharmaceuticals for the containment of decaying microorganisms such as fungi and their spores, bacteria, and yeasts (OLIVIER et al., 1998; SUHR; NIELSEN, 2004; GUYNOT et al., 2005; BRAZIL, 1999; ESFANDIARI et al., 2013), being considered a product with dependent dose action (OLIVIER et al., 1998; FAGUNDES et al., 2013). Has decomposition at temperatures above $270{ }^{\circ} \mathrm{C}$, which favors its use in culture media due to its previous sterilization (SOFOS, 1995). Its inhibitory action has been attributed to the inhibition of enzymes, and the substance may accumulate in the cytoplasmic membrane of microorganisms, interfering in the transport of substrates and oxidative phosphorylation, resulting in mycelial nongrowth and its sporulation (FREESE, SHEU; GALLIERS 1973; SOFOS, 1995; FALLIK et al., 1997; PALMER, HORST; LANGHANS 1997; HEYDARYINIA, VEISSI; SADADI, 2011). Some studies have demonstrated its efficacy in plantations, that is, in the in vivo condition (DELIOPOULOS, KETTLEWELL; HARE 2010; MECTEAU; ARUL; TWEDDELL, 2002), and studies using Potassium Sorbate or its derivatives as inhibitors of microorganisms in vitro are scarce. Due to this gap, this article aimed to evaluate the inhibition of a fungus (Colletotrichum lindemuthianum Sacc. \& Magnus) Briosi \& Cavara 1889 in the presence of different concentrations of potassium sorbate, with a view to its use in vitro plant cultivation.

\section{Material and methods}

\section{Choice of the potassium sorbate food preservative}

The choice of this food preservative was due to the fact that it is already used in the food, cosmetic and pharmaceutical area, has easy to obtain, it has an affordable cost and it has a decomposition temperature above $270{ }^{\circ} \mathrm{C}$, and thus remains stable during the autoclaving process, as well as presenting a versatility as to the broad spectrum of microorganisms whose growth is inhibited (BRAZIL, 1999; GUYNOT et al., 2005; ESFANDIARI et al. , 2013), according to the range of microorganisms that occur in vitro, and also, for presenting low levels of human toxicity, with a median lethal dose of $500 \mathrm{~g}$ in an adult (OLIVIER et al., 1998).

\section{Isolation, choice, and culture medium of the fungus $C$. lindemuthianum}

The phytopathogenic fungus $C$. lindemuthianum was isolated from lesions in the bean (Phaseolus vulgaris L.). Small sterilized fragments of the lesions were collected and inoculated in the center of plates with Potato-Dextrose-Agar (BDA) medium, $20 \mathrm{~mL}$, and kept in the dark at $25 \pm 2{ }^{\circ} \mathrm{C}$ for 72 hours. After isolation and growth in plaques, the fungus was used in the treatments.

The choice of this fungus was due to its ease of isolation and cultivation, as well as the literature showing that fungi of the genus Colletotrichum infect various cultures and some are causing anthracnose disease (MUNCH et al., 2008; DAMM et al., 2010). In addition to infections that can be observed in the in vivo condition, such fungi can also infect explants when inoculated in vitro in the most different plant species, making this fungus quite recurrent in vitro cultivation (HORNER; AUGUSTIN; FORCELINI 2001; MARTIN et al., 2003), taking advantage of the nutritional environment for its development (KRISHNA; SINGH, 2007; ANDRADE et al., 2008). 


\section{Effect of inhibition of mycelial growth of the fungus $C$. lindemuthianum}

With the aid of a $5 \mathrm{~mm}$ hole punch, uniform fragments of $5 \mathrm{~mm}$ diameter of BDA medium were obtained with mycelium of the fungus growing after $72 \mathrm{~h}$ of the previously described isolation (MENTEN et al., 1976). These culture medium discs containing mycelium were inserted in the center of three plates for each of the treatments, as well as in three plates without the presence of potassium sorbate (control).

After inoculation of the discs, the plates remained in the growth room at $25 \pm 2{ }^{\circ} \mathrm{C}$, with a photoperiod of $12 \mathrm{~h}$ for a total time of $72 \mathrm{~h}$, considering that above this time the control plate reaches the maximum growth margin within the culture medium. The mean radial diameter of the fungus growth was performed every 24 hours. The capacity in Percentage of Mycelial Growth Inhibition (ICP) was verified through the equation described by Edgington, Khew and Barron, (1971) with modifications suggested by Menten et al. (1976).

The radial growth of the fungus was always measured on the same axis during the analyzed period, taking as a reference point the center of the sample inoculated at time zero. It was inferred from the sampling center to the edge of mycelial growth, every day at the same time. The center of the $5 \mathrm{~mm}$ sample disc was demarcated, in addition, the same position was always demarcated for the sampling of mycelial growth values to the edge of the mycelium over the test time.

\section{Potassium sorbate concentrations}

Culture media were made with 6 different concentrations of Potassium Sorbate of the Adicel brand, in addition to control. Thus, the following treatments were obtained: T1: Control; T2: $0.076 \mathrm{~g} \mathrm{~L}^{-1}$; T3: $0.15 \mathrm{~g} \mathrm{~L}^{-1}$; T4: $0.30 \mathrm{~g} \mathrm{~L}^{-1}$; T5: $0.45 \mathrm{~g} \mathrm{~L}^{-1}$; T6: $0.60 \mathrm{~g} \mathrm{~L}^{-1}$, and T7: $0.75 \mathrm{~g} \mathrm{~L}^{-1}$. These concentrations were based on previous own studies that used the same food preservative in vitro cultivation, and the results showed that concentrations above $0.75 \mathrm{~g} \mathrm{~L}^{-1}$ caused complete oxidation of the explant and subsequent death, and thus its use would be unfeasible to contain microorganisms for cultivation purposes.

These media were also sterilized $\left(121 \pm 1^{\circ} \mathrm{C}\right.$ and $\left.1.1 \mathrm{~atm}\right)$ for 15 minutes in the autoclave (Prismatec 18L) and were then placed in Petri dishes of $9 \mathrm{~cm}$ in diameter (20 $\mathrm{mL}$ per plate) in a laminar flow chamber. Three plates were made for each treatment.

\section{Statistics}

The data were logarithmized to normalize the values and submitted to statistical analysis of variance through the Tukey and ANOVA test of a factor in the statistical program R (OKSANEN; KINDT; BLANCHET, 2013 - R core Team 2014). The data were represented through graphs with the averages of the triplicates of each treatment and control, together with the standard error of the samples in the Graphpad Prism Version 5.0 program.

\section{Results and discussion}

The different potassium sorbate concentrations tested on the percentage of mycelial inhibition, total growth (72 h), and daily growth rate $(24 \mathrm{~h}$ ) showed significant differences $(p<0.001)$ according to Table 1, evidencing the differences between the beginning of inoculation and up to $72 \mathrm{~h}$ of cultivation. 
Table 1 - Data on the comparison of means (Tukey) in relation to the significance of mycelial growth inhibition, inhibition of growth after $72 \mathrm{~h}$ of incubation and every $24 \mathrm{~h}$.

\begin{tabular}{lccc}
\hline \multicolumn{1}{c}{ Variation } & \multicolumn{3}{c}{ Treatments } \\
\cline { 2 - 4 } & d.f & F & P \\
\hline Inhibition of mycelial growth & 9 & 35.15 & 0,000000919 \\
Growth after 72 hours of incubation & 6 & 67.95 & 0,00000000151 \\
Growth every 24 hours & 6 & 67.95 & 0,00000000151 \\
\hline
\end{tabular}

Source: Elaborated by the authors in University of São Paulo (2019).

Potassium sorbate is used to control different fungal species and their spores with effectively at some specific concentrations and their antifungal action has been attributed to enzyme inhibition, interference in substrate transport, and in the steps oxidative phosphorylation (FREESE; SHEU; GALLIERS, 1973; SOFOS, 1995). Its efficacy is also directly related to $\mathrm{pH}$, and acid media cause greater inhibition in the development of fungi, bacteria, and yeasts (SOFOS, 1995).

In the Figure 1 , it is possible to check that at the lowest concentrations $\left(0.076 \mathrm{~g} \mathrm{~L}^{-1}\right.$ and $0.15 \mathrm{~g} \mathrm{~L}^{-1}$ ) there was a lower inhibition of mycelial growth of the fungus $C$. lindemuthianum after $72 \mathrm{~h}$ of in vitro cultivation, and in the highest percentages of inhibition occurred in the highest concentrations, being $0.30 \mathrm{~g} \mathrm{~L}^{-1}, 0.45 \mathrm{~g} \mathrm{~L}^{-1}, 0.60 \mathrm{~g} \mathrm{~L}^{-1}$, and $0.75 \mathrm{~g} \mathrm{~L}^{-1}$ of the preservative potassium sorbate.

Figure 1 - Percentage of mean inhibition of mycelial growth of the fungus $C$. lindemuthianum after $72 \mathrm{~h}$ of in vitro cultivation under different concentrations of potassium sorbate.

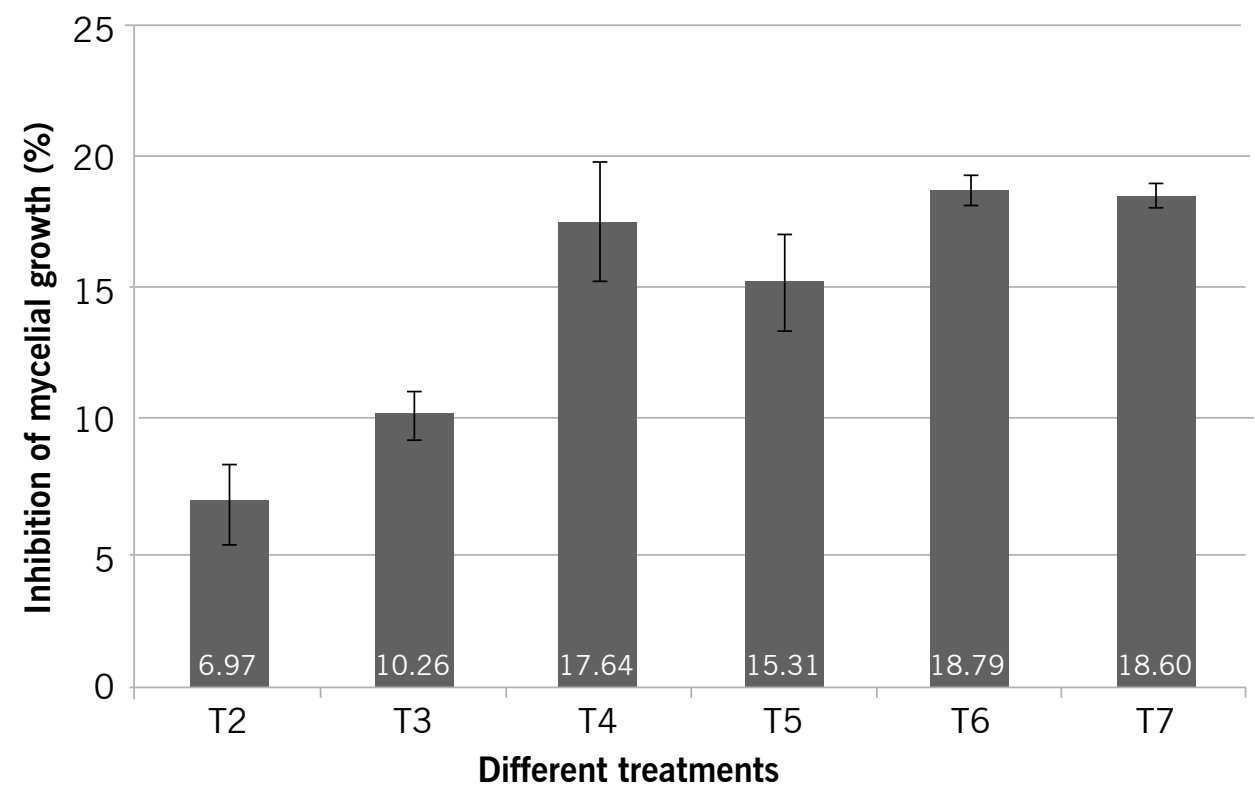

Source: Elaborated by the authors in University of São Paulo (2019).

A few studies and/or reports inform that this preservative is effective in concentrations between $0.5 \mathrm{~g} \mathrm{~L}^{-1}$ and $3.0 \mathrm{~g} \mathrm{~L}^{-1}$ (BRASIL, 1999), not providing the percentage of inhibition or more information. Mecteau, Arul, Tweddell (2002) conducted a study analyzing the different effects of organic and inorganic salts against the phytopathogenic fungus Fusarium sambucinum causing rot in potato tubers. When analyzing mycelial growth and spore germination, the present study found inhibition 
rates of $100 \%$ for both conditions, when analizyng the concentration of $30 \mathrm{~g} \mathrm{~L}^{-1}$ in $24 \mathrm{~h}$ of the experiment. In the present article, at the highest concentration $\left(0.75 \mathrm{~g} \mathrm{~L}^{-1}\right)$ occurred an inhibition rate of $18.6 \%$ and proportionally the inhibition rate was higher, considering that the concentration used was lower, as well as the exposure time was longer (72 h). Although it is also a phytopathogenic fungus, it is evidenced that the responses at the concentration level vary quite from one organism to another, and that high concentrations increase the effect as it is expected of a dose-dependent product.

Al Zaemey, Magan, and Thompson (1993) verified that potassium sorbate was efficient in completely suppressing the banana pathogen Colletotrichum musae at a concentration of $1.25 \mathrm{~g} \mathrm{~L}^{-1}$ in vitro conditions. The highest concentration used in the present article was $0.75 \mathrm{~g} \mathrm{~L}^{-1}$ and this was not efficient in completely suppressing the present phytopathogenic fungus belonging to the same genus, and this may have occurred due to the difference in concentration, which is about 1.6 times higher than used in the present article.

It was also found that at the concentration of $1,000 \mathrm{mg} \mathrm{L}^{-1}$, it occurred $95 \%$ inhibition of fungi that cause sinusitis when potassium sorbate was used in vitro. The highest concentration of the present study was $750 \mathrm{mg} \mathrm{L}^{-1}$ and inhibition was much lower when compared with this study, considering, this time, no similarity to the genus of the tested species (ALSUDANI, 2017).

With the follow-up of mycelial growth every $24 \mathrm{~h}$, a difference in the gain in centimeters was observed in the intervals of total growth, until the plaque was covered with mycelium of the fungus at the end of $72 \mathrm{~h}$ of cultivation. Lower growth averages were observed in the first two treatments with $0.076 \mathrm{~g} \mathrm{~L}^{-1}$ and $0.15 \mathrm{~g} \mathrm{~L}^{-1}$ (T2 and T3) with respect to control and growth averages even lower at concentrations of $0.30 \mathrm{~g} \mathrm{~L}^{-1} ; 0,45 \mathrm{~g} \mathrm{~L}^{-1} ; 0.60 \mathrm{~g} \mathrm{~L}^{-1}$ and $0.75 \mathrm{~g} \mathrm{~L}^{-1}$ (T4 to T7) of potassium sorbate per liter of BDA culture medium (FIGURE 2), thus evidencing that the higher concentrations of potassium sorbate promoted a lower average growth rate.

Figure 2 - Average growth in diameter (centimeters) of the fungus of $C$. lindemuthianum in vitro condition in the 24-hour interval under different potassium sorbate concentrations.

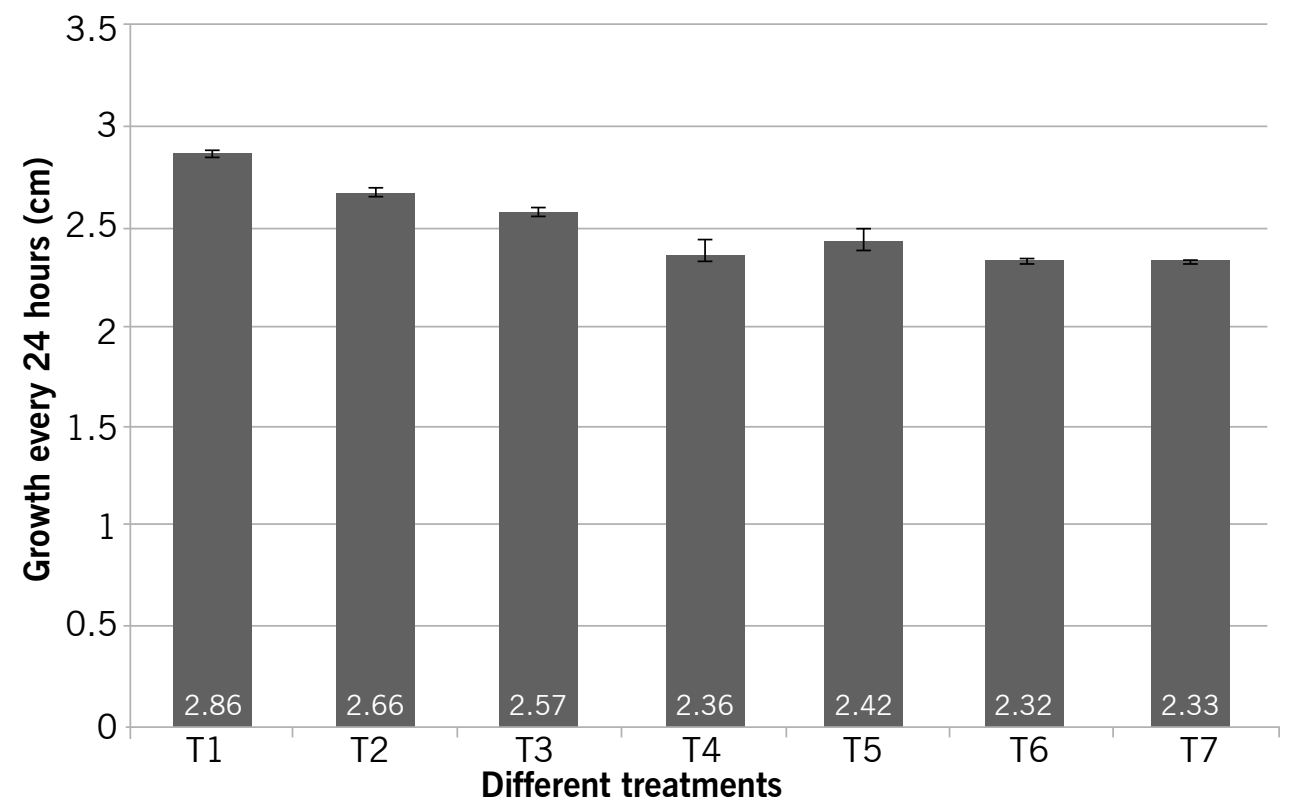

Source: Elaborated by the authors in University of São Paulo (2019). 
It was also verified that after $72 \mathrm{~h}$ of in vitro cultivation the fungus $C$. lindemuthianum came to colonize $90 \%$ of the plaque in T1 (control), and at the highest concentrations (T5 to T7: $0.45 \mathrm{~g} \mathrm{~L}^{-1}$, $0.60 \mathrm{~g} \mathrm{~L}^{-1}$, and $0.75 \mathrm{~g} \mathrm{~L}^{-1}$ ) such colonization reached $70 \%$, causing, therefore, a reduction of plate colonization of $20 \%$ (FIGURE 3).

Figure 3 - Comparison of mycelial growth after $72 \mathrm{~h}$ of in vitro cultivation of T1, T5, T6, and T7 plates, respectively, evidencing the decrease in the colonization of the fungus $C$. lindemuthianum in the presence of potassium sorbate.

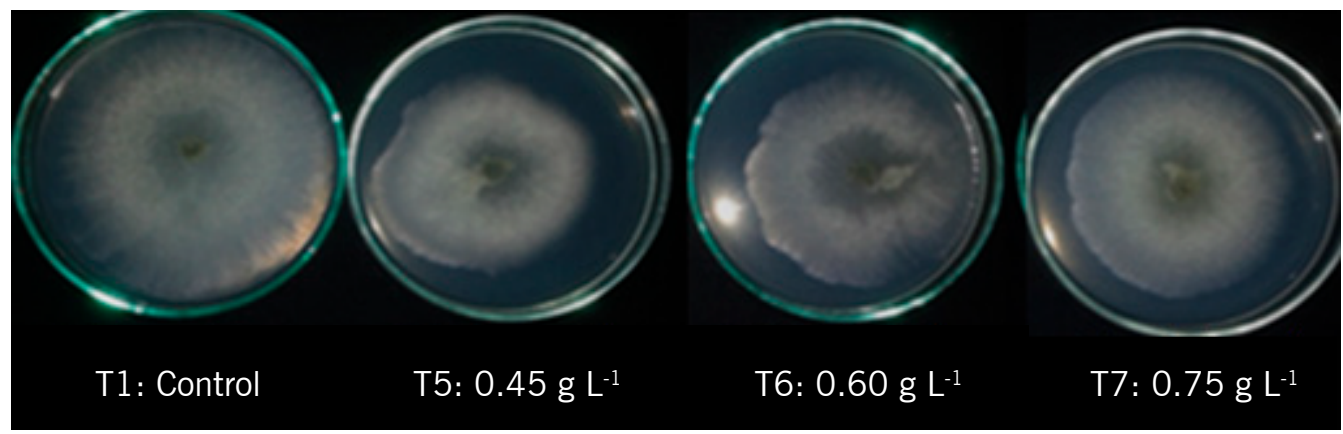

Source: Elaborated by the authors in University of São Paulo (2019).

These results were obtained from the average total growth of the present fungus after $72 \mathrm{~h}$ of cultivation (FIGURE 4).

Figure 4 - Comparison of the mean mycelial growth in diameter (centimeters) of the fungus $C$. lindemuthianum after $72 \mathrm{~h}$ of cultivation under different concentrations of potassium sorbate.

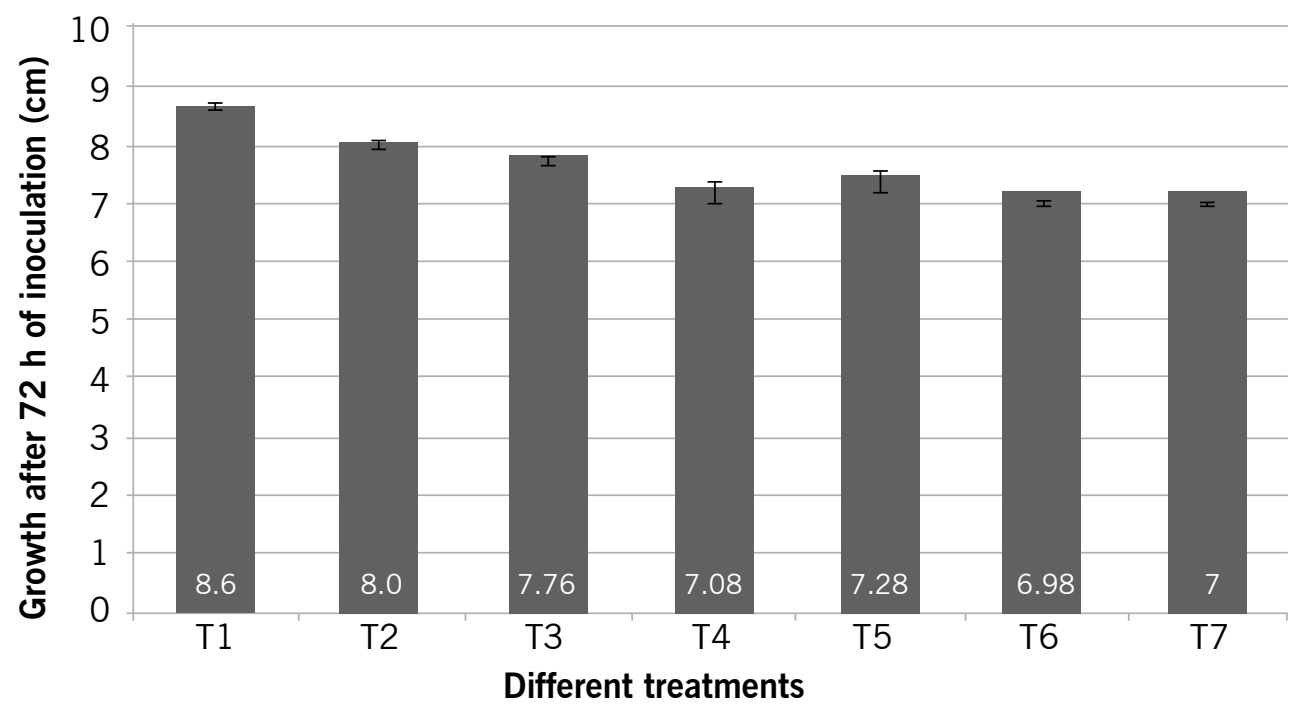

Source: Elaborated by the authors in University of São Paulo (2019).

It is noteworthy that although the plaque was colonized by the fungus even at the highest concentration of potassium sorbate $\left(0.75 \mathrm{~g} \mathrm{~L}^{-1}\right)$, it is known that when manipulating an explant in vitro cultivation contamination occurs in much lower proportions than those practiced in the present study, considering all the asepsis processes that are previously performed according to studies (GRATTAPAGLIA; MACHADO, 1998; MORAES et al., 2007). Thus, it is suggested that with the 
asepsis performed previously and with the other care that should be adopted during the cultive and the following phases of multiplication, the percentage of inhibition can certainly be well above the $20 \%$ observed, it and may even result in a material free of contamination.

It is already known that there are several alternatives in the control of fungal contamination in vitro cultivation, such as those mentioned previously and in relation to their use in the culture media, studies have revealed that the use of some fungicides such as Benomil, Chlorothalonil, and Azoxistrobin demonstrated lethal effects for explants of a orchid and eucalyptus specie, even at the lowest concentrations studied, also evidencing its toxic characteristics to the environment (WATT; GAUNTLETT; BLAKEWAY, 1996; ODA et al., 2003), and therefore, potassium sorbate may add up as a strategy to combat fungi observed in vitro, by the characteristics already presented.

Thus, considering that there are still some gaps in the disinfection processes for in vitro multiplication,

as well as risks and unfeasibility in using commercial fungicides to combat fungal contamination in vitro, the food preservative potassium sorbate can be a product to be used to control the development of fungi in plant crops in the in vitro multiplication stage, given the results presented, which may help in a significant reduction of plant material losses due to contamination, which, in some cases, may cause the unsuccess of in vitro multiplication of plant species with consequent commercial loss, as well as the infeasibility of these in vitro cell culture laboratories (CASSELS, 1991; CASSELLS, 1997).

\section{Conclusions}

Treatments from T4 to T7 had statistically equal and higher inhibition performances in relation to T2 and T3 treatments. The highest inhibition percentages occurred from T5 to T7 with an average inhibition rate of $17.5 \%$ for the $72 \mathrm{~h}$ period, although the increase in potassium sorbate concentration also caused a higher percentage of inhibition, regardless of time, in all treatments.

The present study indicated that potassium sorbate can provide a control of the fungus C. lindemuthianum, and more information about its antifungal activities in the combat of in vitro microorganisms correlated with plant cell cultivation need to be elucidated.

\section{Acknowledgements}

To the Coordination for the Improvement of Higher Education Personnel (Capes) and the National Council for Scientific and Technological Development (CNPq), for the scholarships granted during the realization of this research.

\section{Inibição do fungo Colletotrichum lindemuthianum na presença de diferentes concentrações de sorbato de potássio}

\section{Resumo}

Um dos grandes problemas do cultivo vegetal in vitro é causado por contaminações como as fúngicas, que representam grandes perdas para os laboratórios de cultivo vegetal. Diante da problemática acerca das contaminações e das lacunas em protocolos eficientes de desinfecção, o presente estudo teve como objetivo avaliar a inibição do fungo Colletotrichum lindemuthianum na presença do conservante alimentar Sorbato de Potássio em diferentes concentrações (T1: controle, T2: 0,076 g L"-1; 
T3: 0,15 g L-1; T4: 0,30 g L-1; T5: 0,45 g L-1; T6: 0,60 g L-1 e T7: 0,75 g L-1). Quantificaram-se as análises da Porcentagem de Inibição do Crescimento Micelial (PIC) e o crescimento em 24 e 72 horas em diferentes concentrações. Observou-se que o Sorbato de Potássio foi efetivo na análise de PIC nas diferentes concentrações com relação ao controle, com maior efetividade para o T4 a T7. As maiores porcentagens de inibição (T5 a T7) tiveram uma taxa de inibição média de 17,5 \% em relação ao controle para o período de $72 \mathrm{~h}$, indicando, portanto, que com mais estudos este conservante pode ser utilizado no combate a microrganismos fúngicos no cultivo in vitro.

Palavras-chave: Inibição de microrganismos. Contaminação in vitro. Inibição fúngica. Crescimento micelial. Conservante alimentar.

\section{References}

AL ZAEMEY, A. B.; MAGAN, N.; THOMPSON, A. K. Studies on the effect of fruit-coating polymers and organic acids on growth of Colletotrichum musae in vitro and on postharvest control of anthracnose of bananas. Mycological Research, v. 97, n. 12, p. 1463-1468, 1993. DOI: https://doi.org/10.1016/ S0953-7562(09)80218-9.

ALSUDANI, A. A. In vitro antifungal effect of potassium sorbate and sodium benzoate on the growth of fungi causing sinusitis. African Journal of Microbiology Research, v. 11, n. 6, p. 232-236, 2017. DOI: https://doi.org/10.5897/AJMR2016.8414.

ANDRADE, S. R. M.; OLIVEIRA, W. C.; REIS JUNIOR, F. B.; CHARCHAR, M. J. D. A.; FALEIRO, F. G.; MEHTA, A.; PEIXOTO, J. R. Controle do crescimento e identificação de microrganismos contaminantes visando à micropropagação de gemas laterais de mangueira. Planaltina: Embrapa Cerrados. 2008. 28p.

BRASIL. Resolução RDC n.389, de 05 de agosto de 1999. 16: bebidas - subcategoria 16.2.2 bebidas não alcoólicas gaseificadas e não gaseificadas. Diário Oficial da República Federativa do Brasil, Poder Executivo, Distrito Federal, Brasil. Seção 1. 45-53.

CASSELS, A. C. Contamination and its impact in tissue culture. IV International symposium on in vitro culture and horticultural breeding, 560, 2000a.

CASSELLS, A. C. 1991. Problems in tissue culture: culture contamination. In: DEBERGH, P. C.; ZIMMERMAN, R. H. (Ed.). Micropropagation: technology and application. Dordrecht: Kluwer Academic, 1991. p. 31-44.

CASSELLS, A. C. Asseptic microhydroponics: a strategy to advance microplant development and improve microplant physiology. Acta Horticulturae, v. 530, p. 187-194, 2000b. DOI: 10.17660/ ActaHortic.2000.530.21.

CASSELLS, A. C. Pathogen and microbial contamination management in micropropagation. Dordrecht: Springer, 1997. 371 p.

COLOMBO, L. A.; FARIA, R. T.; CARVALHO, J. F. R. P.; ASSIS, A. M.; FONSECA, I. C. B. Influência do fungicida clorotalonil no desenvolvimento vegetativo e enraizamento in vitro de duas espécies de orquídeas brasileiras. Acta Horticulturae, v. 26. n. 2, p. 253-258, 2004. DOI: https://doi.org/ 10.4025/actasciagron.v26i2.1893. 
DAMM, U.; BARONCELLI, R.; CAI, L.; KUBO, Y.; O'CONNELL, R.; WEIR, B.; CANNON, P. F. Colletotrichum: species, ecology and interactions. IMA Fungus, v. 1, n. 2, p. 161-165, 2010. DOI: 10.5598/imafungus.2010.01.02.08.

DELIOPOULOS, T.; KETTLEWELL, P. S.; HARE, M. C. Fungal disease suppression by inorganic salts: A review. Crop Protection, v. 29, p. 1059-1075, 2010. DOI: https://doi.org/10.1016/j. cropro.2010.05.011.

EDGINGTON, L. V.; KHEW, K. L \& BARRON, G. L. Fungitoxic spectrum of benzimidazoles compounds. Phytopathology, v. 61, p. 42-44, 1971.

EMMANUEL, E.; HECK, G.; BLANCHARD, J.; VERMANDE, P.; PERRODIN, Y. Toxicological effects of disinfestations using sodium hypochlorite on aquatic organisms and its contribution to AOX formation in hospital wastewater. Environment Internacional, v. 30, p. 891-900, 2004. DOI: https://doi.org/ 10.1016/j.envint.2004.02.004.

ESFANDIARI, Z.; BADIEY, M.; MAHMOODIAN, P.; SARHANG-POUR, R.; YAZDANI, E.; MIRLOHI, M. Simultaneous determination of sodium benzoate, potassium sorbate and natamycin content in Iranian yoghurt drink (Doogh) and the associated risk of their intake through Doogh consumption. Iranian Journal of Public Health, v. 42, p. 915-920, 2013.

FAGUNDES, C.; PÉREZ, M. B.; MONTEIRO, A. R.; PALOU, L. Antifungal activity of food additives in vitro and as ingredients of hydroxypropyl methylcelluloselipid edible coatings against Botrytis cinerea and Alternaria alternata on cherry tomato fruit. International Journal of Food Microbiology, v. 166, p. 391-398, 2013. DOI: https://doi.org/10.1016/j.ijfoodmicro.2013.08.001.

FALLIK, E.; ZIV, O.; GRINBERG, S.; ALKALAI, S.; KLEIN, J. D. Bicarbonate solutions control powdery mildew (Leveillula taurica) on sweet red pepper and reduce the development of postharvest fruit rotting. Phytoparasitica, v. 25, p. 41-43, 1997. DOI: https://doi.org/10.1007/BF02981478.

FREESE, E.; SHEU, C. W.; GALLIERS, E. Function of lipophilic acids as antimicrobial food additives. Nature, v. 241, p. 321-325, 1973. DOI: https://doi.org/10.1038/241321a0.

GEORGE, E. F. Plant propagation by tissue culture. 2. ed. Edington: Exegetics, 1993. 574p.

GRATTAPAGLIA, D.; MACHADO, M. A. Micropropagação. In: TORRES, A. C.; CALDAS, L. S.; BUSO, J. A. (Ed.). Cultura de tecidos e transformação genética de plantas. Brasília: Embrapa/SPI, 1998. p. 183-260.

GUYNOT, M. E.; RAMOS, A. J.; SANCHIS, V.; MARIN, S. Study of benzoate, propionate, and sorbate salts as mould spoilage inhibitors on intermediate moisture bakery products of low $\mathrm{pH}$ (4.5- 5.5). International Journal of Food. Microbiology, v. 101, p. 161-168, 2005. DOI: https://doi.org/10.1016/j. ijfoodmicro.2004.11.003.

HEYDARYINIA, A.; VEISSI, M.; SADADI, A. A comparative study of the effects of the two preservatives, sodium benzoate and potassium sorbate on Aspergillus niger and Penicillium notatum. Jundishapur Journal of Microbiology, v. 4, n. 4, p. 301-307, 2011. 
HIRATA, M. H.; MANCINI-FILHO, J. Manual de biossegurança. Barueri: Manole, 2002. 496p.

HORNER, L. de A.; AUGUSTIN, L.; FORCELINI, C. A. Estudo do desenvolvimento e identificação dos agentes contaminantes da erva-mate cultivada in vitro. In: CONGRESSO SUL-AMERICANO DA ERVA MATE, 2.; REUNIÃO TÉCNICA DA ERVA MATE, 3. 2000. Encantado. Anais... Porto Alegre: Comissão dos Organizadores; Universidade do Rio Grande do Sul; Fundação de Pesquisa Agropecuária, 2001. p. 453-456.

KRISHNA, H.; SINGH, S. K. Biotechnological advances in mango (Mangifera indica L.) and their future implications in crop improvement - A review. Biotechnology Advances, v. 25, p. 223-243, 2007. DOI: https://doi.org/10.1016/j.biotechadv.2007.01.001.

LEIFERT, C.; CASSELLS, A. C. Microbial hazards in plant tissue and cell cultures. In vitro Cellular \& Developmental Biology - Plant, v. 37, p. 133-138, 2003. DOI: https://doi.org/10.1007/s11627-001-0025-y.

LEIFERT, C.; MORRIS, C. E.; WAITES, W. M. Ecology of microbial saprophytes and pathogens in tissue culture and field grown plants: reason for contamination problems in vitro. Critical Reviews in Plant Sciences, v. 13, p. 139-183, 1994. DOI: https://doi.org/10.1080/07352689409701912.

MARTIN, M. C.; SUAREZ, M. A.; PÉREZ, A. C.; MICHEL, L. M.; CAPÓ Y. A. Efecto del carbendazim para el control de Colletotrichum sp., contaminante del establecimiento in vitro de callos de café. Biotecnología Vegetal, v. 3, n. 2, p.111-113, 2003.

MECTEAU, M. R.; ARUL, J.; TWEDDELL, R. J. Effect of organic and inorganic salts on the growth and development of Fusarium sambucinum, a causal agent of potato dry rot. Mycology Research, v. 106, n. 6, p. 688-696, 2002. DOI: https://doi.org/10.1017/S0953756202005944.

MENTEN, J. O. M.; MACHADO, C. C.; MUNISSI, E.; CASTRO, C.; KIMATI, H. Efeito de alguns fungicidas no crescimento micelial de Macrophomina phaseolina (Tass.) Goid "in vitro". Fitopatologia Brasileira, v. 1, p. 57-66, 1976.

MORAES, R. M.; CALDAS, L. S.; SILVEIRA, C. E. S.; SOUZA, A. V.; BERTONI, B. W.; PEREIRA, A. M. S. Micropropagação e Banco de Germoplasma "in vitro" para produção e conservação de plantas nativas do Cerrado. In: PEREIRA, A. M. S. (Ed.). Recursos genéticos e conservação de plantas medicinais do Cerrado. Ribeirão Preto: Editora Legis Summa, 2007. v. 1, p. 185-214.

MUNCH, S.; LINGNER, U.; FLOSS, D. S.; LUDWIG, N.; SAUER, N.; DEISING, H. B. The hemibiotrophic lifestyle of Colletotrichum species. Journal of Plant Physiology, v. 165, n. 1, p. 41-51, 2008. DOI: https://doi.org/10.1016/j.jplph.2007.06.008.

ODA, M. L.; FARIA, R. T.; FONSECA, I. C. B.; SILVA, G. L. Avaliação da fitotoxicidade de fungicidas e germicidas na propagação in vitro de Oncidium varicosum Lindl. (Orchidaceae) para o controle de microrganismos. Semina: Ciências Agrárias, v. 24, n. 2, p. 273-276, 2003.

OKSANEN, J.; KINDT, R.; BLANCHET, F. G. Vegan: community ecology package. R package version 2.0-9. 2013. Disponível em: http://CRAN.R-project.org/package=vegan. Acesso em: 26 jan. 2021. 
OLIVIER, C.; HALSETH, D. E.; MIZUBUTI, E.; LORIA, R. Postharvest application of organic and inorganic salts for suppression of silver scurf on potato tubers. Plant Disease, v. 82, p. 213-217, 1998. DOI: https://doi.org/10.1094/PDIS.1998.82.2.213.

PALMER, C. L.; HORST, R. K.; LANGHANS, R. W. Use of bicarbonates to inhibit in vitro colony growth of Botrytis cinerea. Plant Disease, v. 81, p. 1432-1438, 1997. DOI: https://doi.org/10.1094/ PDIS.1997.81.12.1432.

PASQUAL, M. Meios de cultura. Lavras: UFLA-FAEPE, 2001. 74p.

PIERIK, R. L. M. In vitro culture of higher plants. 1a ed. The Nertherlands: Kluwer Academic Publishers, 1997. 348p.

R Core Team. R: a language and environment for statistical computing. $\mathrm{R}$ foundation for statistical computing, Vienna, Austria. 2014. Disponível em: http://www.R-project.org/. Acesso em: 26 jan. 2021.

SOFOS, J. N. Antimicrobial agents. In: MAGA, J. A.; TU, A. T. (Eds.). Food additive toxicology. Marcel Dekker, New York, United States, 1995. p. 501-529.

SUHR, K. I.; NIELSEN, P. V. Effect of weak acid preservatives on growth of bakery product spoilage fungi at different water activities and $\mathrm{pH}$ values. International Journal of Food Microbiology, v. 95, p. 67-78, 2004. DOI: https://doi.org/10.1016/j.ijfoodmicro.2004.02.004.

TORRES, A.C.; FERREIRA, A. T.; SÀ, F. G. de.; BUSO, J. A.; CALDAS, L. S.; NASCIMENTO, A. S.; BRIGIDO, M. de M.; ROMANO, E. 2000. Glossário de biotecnologia vegetal. Embrapa Hortaliças, Brasília, 128p.

VIANA, G. R. COUTO, F. A. A.; OLIVEIRA, A. B.; ZAMBOLIM, L.; MARIA, J. A rifampicina na descontaminação bacteriana de explantes de mamoeiro provenientes do campo. Bragantia, v. 56, p. 249-254, 1997. DOI: https://doi.org/10.1590/S0006-87051997000200003.

WATT, M. P.; GAUNTLETT, B. A.; BLAKEWAY, F. C. Effect of anti-fungal agents on in vitro cultures of Eucalyptus grandis. South African Forestry Journal, v. 175, n.1, p. 23-27, 1996. DOI: https://doi.org/10.1080/00382167.1996.9629889.

YEPES, M. L.; ALDWINCKLE, H. S. Micropropagation of thirteen Malus cultivars and rootstocks, and effect of antibiotic on proliferation. Plant Growth Regulation, v. 15, p. 55-67, 1994. DOI: https://doi.org/10.1007/ BF00024677.

Received: June 4, 2020

Accepted: November 12, 2020 